\title{
Studi Literatur Penggunaan Sensor untuk Sistem Deteksi Gempa
}

\author{
Literature Study on the Use of Sensors for Earthquake Detection System
}

Rizki Kurniawati ${ }^{*}$, Muhammad Ary Murti²

${ }^{1,2}$ Program Studi Teknik Elektro Fakultas Teknik Elektro, Universitas Telkom

\begin{tabular}{l}
\hline \hline ARTICLE INFO \\
\hline Article history: \\
DOI: \\
10.30595/pspfs.v1i.126 \\
Submitted: \\
June 25, 2021 \\
Accepted: \\
July 10, 2021 \\
Published: \\
Oct 31, 2021 \\
\hline
\end{tabular}

\begin{abstract}
As a country located among three major tectonic plate confluences, namely the Eurasian Plate, the Indo-Australian Plate, and the Pacific Plate, Indonesia is an earthquake-prone area. Information about the earthquake occurrences is distributed by the BMKG through social media, websites and television. However, it is undeniable that there are still people who do not have televisions or smartphones. Therefore, earthquake warning systems began to be widely developed. Furthermore, sensors for earthquake vibration detection have an important role in earthquake warning systems. So in this article, the author has conducted a literature study and analysis of the sensors commonly used in earthquake detection systems. This study aimed to present sensor recommendations to be used as earthquake sensors. The result of the literature study, that the author had done, is the selection of sensors is customized to the needs and budget of the project. A description of the sensor recommendations for each project has also been included in this article.
\end{abstract}

This work is licensed under a Creative Commons Attribution 4.0 International License.

Keywords:

Earthquake sensor,

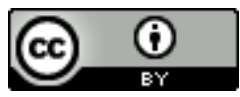

Accelerometer, Seismometer

\section{Corresponding Author:}

Rizki Kurniawati

Program Studi Teknik Elektro Fakultas Teknik Elektro, Universitas Telkom

J1 Telekomunikasi, Dayeuhkolot, Bandung 40257 Telp. (022) 7566456

Email: rizkikurnia@student.telkomuniversity.ac.id

\section{PENDAHULUAN}

Indonesia terletak diantara tiga pertemuan lempeng tektonik besar, yaitu Lempeng Eurasia, Lempeng IndoAustralia, dan Lempeng Pasifik. Hal tersebut menjadikan Indonesia sebagai salah satu daerah rawan gempa, bahkan Indonesia menduduki peringkat ke-2 dunia daerah rawan gempa (Liputan6, n.d.). Berdasarkan catatan BMKG (Badan Meteorologi, Klimatologi, dan Geofisika), tahun 2008-2018 ada sekitar 5000-6000 gempa. Dan pada tahun 2019 sudah terjadi 15 kali gempa merusak (CNN, n.d.).

Dalam mendapatkan informasi mengenai gempa yang sedang terjadi, mayoritas warga negara Indonesia mengandalkan informasi dari pemerintah melalui BMKG. Namun terkadang informasi dari BMKG terlambat sampai ke warga yang terdampak gempa. Dan tidak dapat dipungkiri juga bahwa masih ada warga yang belum bisa memiliki atau mengoperasikan handphone. Sehingga banyak peneliti yang merancang Early Earthquake Warning (EEW) agar warga bisa mendapatkan peringatan dan informasi ketika terjadi gempa lebih cepat.

Pada artikel ini, akan dibahas performa sensor yang digunakan untuk EEW. Penelitian ini dilaksanakan dengan metode studi literatur, dan akan dilakukan analisa untuk menentukan sensor yang baik digunakan sebagai sensor gempa, serta dipertimbangkan juga berdasarkan harganya.

\section{METODE PENELITIAN}

Penelitian ini dilakukan dengan metode studi literatur menggunakan jurnal-jurnal penelitian mengenai sistem deteksi gempa. Jurnal-jurnal penelitian ini kemudian di analisa dengan metode sebagai berikut: 
1. Klasifikasi sensor dan spesifikasi

Sensor yang digunakan akan diklasifikasikan menjadi sensor yang di desain khusus untuk gempa dan sensor getar/akselerometer biasa. Selain itu, spesifikasi sensor dari datasheet juga akan disajikan dalam artikel ini.

2. Perbandingan metode pengujian

Sensor gempa dapat di uji dengan menggunakan banyak cara. Pada penelitian ini, metode pengujian sensor yang digunakan akan di analisa. Perbedaan dalam pengujian tentu akan membuat hasil akurasi sensor berbeda.

3. Perbandingan hasil pengujian

Hasil pengujian sensor gempa akan dibandingkan untuk menentukan sensor yang sesuai untuk sistem deteksi gempa.

4. Analisa performa sensor

Kemudian akan dilakukan analisa performa sensor dilihat dari nilai akurasi maupun presisi dengan memperhatikan metode pengujiannya.

\section{HASIL DAN PEMBAHASAN}

Terdapat 9 sensor yang akan di analisa pada artikel ini, dengan 6 sensor pertama di bawah ini merupakan sensor getaran juga percepatan yang tidak di khususkan untuk deteksi gempa, harganya pun termasuk low budget. Dan 3 sensor yang memang sudah di desain khusus untuk deteksi gempa, dan harganya cukup mahal, yaitu sensor geophone, Omron D7S, dan seismometer Trillium 120P.

\section{Accelerometer ADXL330}

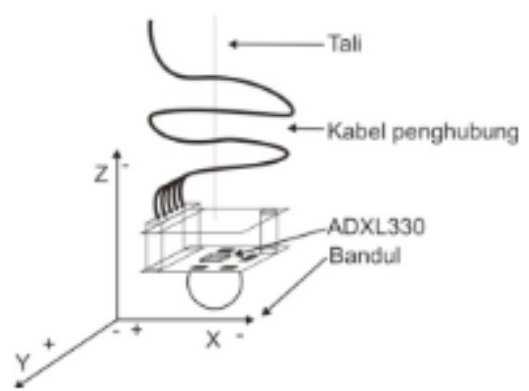

Gambar 1 Pengujian accelerometer ADXL330 (Hidayat, Ishaq, \& Lasa, 2012)

Fitur

- 3-axis

- low power: $200 \mu \mathrm{A}$ pada $\mathrm{V}_{\mathrm{s}}=2 \mathrm{~V}$

- bertahan hingga $10.000 \mathrm{~g}$

- range $\pm 3 \mathrm{~g}$

- single-supply operation : 2-3,6 V

Pada (Hidayat et al., 2012), mereka membuat pengukur magnitudo dan arah gempa dengan menggunakan sensor ADXL330. Metode pengujiannya adalah dengan menempatkan sensor pada bandul, kemudian digerakkan ke selatan, utara, barat, timur, timur laut, barat daya, tenggara dan barat laut. Hasil pengujian menunjukkan bahwa alat yang dibuat menggunakan sensor ADXL330 berhasil mengukur magnitudo juga arah dari gempa.

\section{Accelerometer ADXL335}

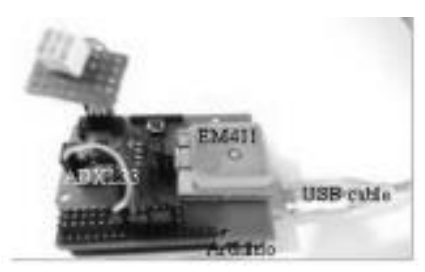

Gambar 2 Sensor gempa menggunakan ADXL335 (Priyana, Laumal, \& Husni, n.d.)

Fitur

$$
\begin{aligned}
& \text { - 3-axis } \\
& \text { - low power: } 350 \mu \mathrm{A} \\
& \text { - range } \pm 3 \mathrm{~g}
\end{aligned}
$$

- bertahan hingga $10.000 \mathrm{~g}$

- single-supply operation : 1,8-3,6 V 
(Ardhi, Murti, \& Nugraha, 2018) membuat alat pendeteksi gempa dengan menggunakan sensor percepatan ADXL335 dan sensor getar. Metode pengujian alat yang digunakan adalah dengan menggunakan beban $1 \mathrm{~kg}, 2 \mathrm{~kg}$, dan $3 \mathrm{~kg}$ yang dijatuhkan dari jarak $0 \mathrm{~cm}, 15 \mathrm{~cm}$ dan $25 \mathrm{~cm}$ dari sistem. Sementara itu untuk pengujian sensor ADXL335 dilakukan uji sensitivitas dengan mengukur tegangan keluaran sensor dan perbandingan dengan accelerometer smartphone. Error rate dan sensitivitas pada sumbu x sensor ADXL335 adalah 0,30\% dan 0,296 V/g, pada sumbu y $0,30 \%$ dan $0,2885 \mathrm{~V} / \mathrm{g}$, dan pada sumbu z 0,017\% dan 0,33 V/g. Sistem dapat mendeteksi dan memberi peringatan gempa bumi sesuai dengan data dari British Geological Survey.

Pada penelitian (Sharma, 2017), metode pengujian sensor tidak disampaikan dengan jelas, dan hasil pengujiannya adalah sensor dapat mengukur percepatan statis gravitasi, gerakan, maupun getaran.

Penelitian (Priyana et al., n.d.) mengenai pengembangan sistem EEW juga tidak mencantumkan metode pengujian sensor dengan jelas. Sensor ADXL335 yang digunakan berhasil buffered, calibrated, mengirimkan dan display data P-wave ke server.

\section{Accelerometer ADXL345}

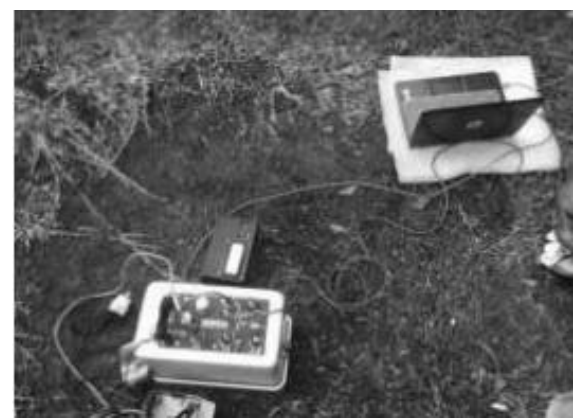

Gambar 3 Pengujian ADXL345 (Darmawan, Mulyasari, Amirudin, Efendi, \& Suharno, 2019)

Fitur

$$
\begin{array}{ll}
\text { - 3-axis } & \text { - bertahan hingga } 10.000 \mathrm{~g} \\
\text { - low power: } 0,1 \mu \mathrm{A} \text { pada } \mathrm{V}_{\mathrm{s}}=2,5 \mathrm{~V} & \text { - single-supply operation }: 2-3,6 \mathrm{~V} \\
\text { - range hingga } \pm 16 \mathrm{~g} & \text { - antarmuka digital: } \mathrm{SPI}, \mathrm{I}^{2} \mathrm{C}
\end{array}
$$

(Darmawan et al., 2019) melakukan uji validasi akselerometer ADXL345 dengan membandingkan nilai frekuensi dominan sensor dengan akselerometer buatan pabrik yaitu SMHR-Accelerograph REFTEK. Pengukuran dilakukan pada 30 titik akuisisin di Universitas Lampung. Sensor ADXL345 berhasil mendeteksi pola kerentanan gempa sesuai dengan akselerometer REFTEK dengan nilai korelasi 62\%

(Sampurno, Sugiana, Rusdinar, Elektro, \& Telkom, 2018) membuat sistem peringatan gempa bumi pada jalur kereta api menggunakan akselerometer ADXL345. Pengujian sensor dilakukan sebanyak 32 kali dengan cara mengguncangkan perangkat peringatan gempa. Tingkat akurasi dan presisi yang didapatkan adalah 98,69\% dan $99,74 \%$ pada sumbu x, pada sumbu y sebesar $96,2 \%$ dan $99,75 \%$ dan pada sumbu z sebesar $85,93 \%$ dan $99,79 \%$. Sistem yang dibuat mampu mendeteksi guncangan dan mengubahnya menjadi percepatan dan magnitudo gempa bumi.

\section{Accelerometer MPU6050}

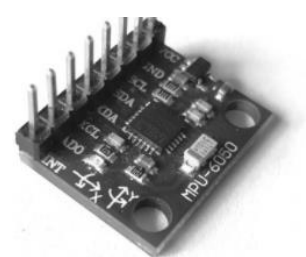

Gambar 4 Accelerometer MPU6050 (Components101, n.d.)

Fitur
- 3-axis accelerometer dan gyroscope
- tegangan operasi : $3-5 \mathrm{~V}$
- komunikasi $\mathrm{I}^{2} \mathrm{C}$
- 16-bit ADC 
Pada penelitian (Santoso, Quszaini, Aris, \& Andriawan, n.d.), sistem diuji dengan membuat getaran kecil dan sedang dengan jarak $10 \mathrm{~cm}, 20 \mathrm{~cm}$, dan $30 \mathrm{~cm}$ dari sistem. Hasil dari pengujian ini menunjukkan bahwa pembacaan akselerometer hampir sama dengan tabel skala intensitas gempa. Pada jarak $10 \mathrm{~cm}$ menghasilkan percepatan (a) > 9.81 , pada jarak $20 \mathrm{~cm}$ a $>5.67$, dan pada jarak $30 \mathrm{~cm}$ a $>5.04$.

\section{Accelerometer $\mathrm{H} 48 \mathrm{C}$}

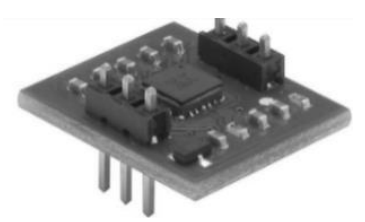

Gambar 5 Accelerometer $\mathrm{H} 48 \mathrm{C}$

Fitur

$$
\text { - 3-axis - range } \pm 3 \mathrm{~g} \quad \text { - sensitivitas: } 366.3 \mathrm{mV} / \mathrm{g}
$$

(Fadlilah \& Arifudin, 2018) membuat alat pendeteksi gempa menggunakan accelerometer H48C. Alat tersebut diuji dengan menggerakkan-gerakkan sensor. Hasilnya alat yang dibuat menggunakan Accelerometer H48C tersebut dapat berjalan sesuai harapan peneliti, H48C dapat mendeteksi adanya getaran.

\section{Sensor Getar SW-420}

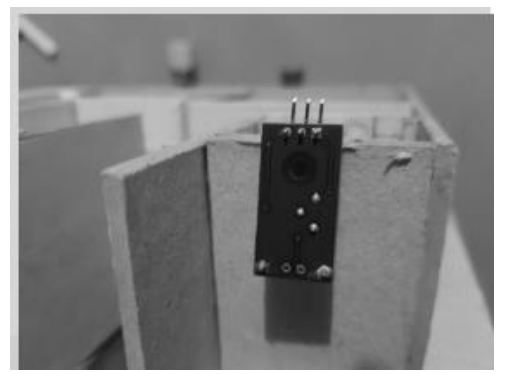

Gambar 6 Sensor Getar SW-420 Pada Prototype Rumah (Saputra, Rosmiati, \& Sari, 2018)

Fitur

$$
\begin{aligned}
& \text { - murah dan mudah didapatkan } \\
& \text { - IC LM393 }
\end{aligned}
$$

- operating current : $15 \mathrm{~mA}$

- tegangan operasi : 3,3 -5 V

(Burhannudin, 2020) menggunakan sensor getar SW-420 pada prototype pendeteksi dini gempanya. Sensor getar tersebut pun diuji menggunakan getaran dari alat pijit dengan level getaran 1-5. Hasil pengujian menunjukkan bahwa sensor getar tidak aktif pada level 1-2 alat pijit, dan pada level 3-5 menghasilkan pulsa 15.322,-28.602,4 yang dikonversikan menjadi 5-10 Skala Richter (SR).

(Alam, Kusuma, \& Prayogi, 2020) memberi getaran buatan pada sensor sebagai metode pengujian sensor getar SW-420. Getaran yang dideteksi adalah arah vertikal dan horizontal, mencakup 3600, sensor juga dapat digunakan utuk mendeteksi getaran yang sangat kecil.

(Saputra, Rosmiati, \& Sari, 2018) membuat prototype rumah untuk pengujian alat yang kemudian prototype rumah tersebut digoyangkan sebagai getaran buatan. Dari hasil Pengujian yang telah dilakukan, sistem yang dibangun menggunakan sensor getar SW-420 bisa mendeteksi getaran gempa, dan sistem berhasil menunjukan titik koordinat lokasi secara realtime. 
7. Sensor Geophone

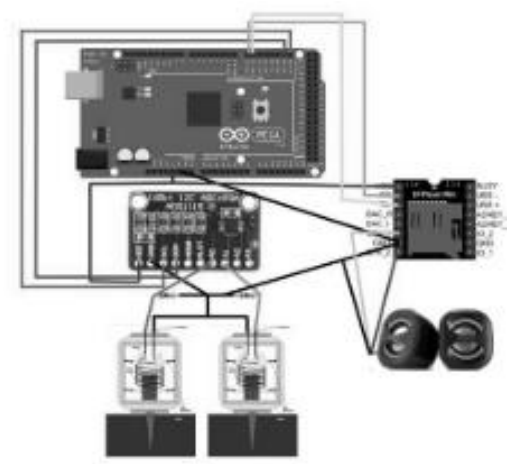

Gambar 7 Gambaran Rangkaian Pengujian (Anugerah et al., n.d.)

Fitur

\author{
- low distortion \\ - sensitivitas $28,8 \mathrm{~V} / \mathrm{m} / \mathrm{s}$
}

- bandwidth 10 - $240 \mathrm{~Hz}$

Pada penelitian (Anugerah et al., n.d.), pengujian sensor geophone dilakukan dengan menjatuhkan batu seberat $10 \mathrm{~kg}$ dengan jarak $40 \mathrm{~cm}$ dari tanah, dan deteksi getaran pada saat truk melintas. Dari hasil pengujian, sensor dapat mendeteksi getaran tanah dan alat yang dirancang berhasil mendeteksi getaran gempa.

8. Sensor Omron D7S

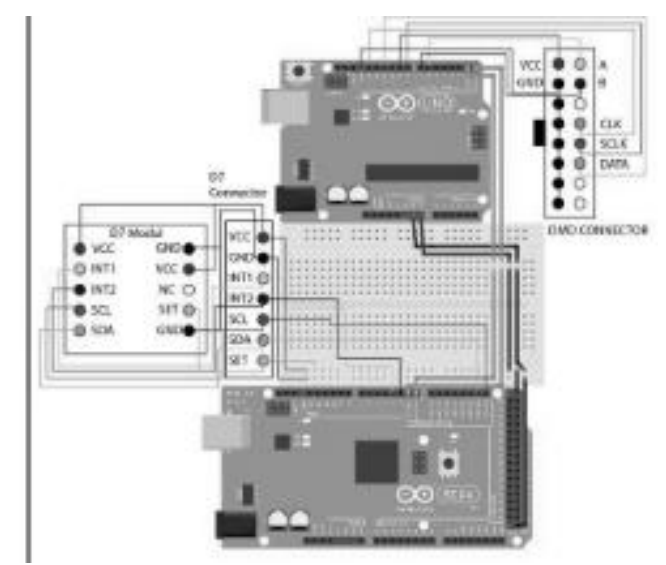

Gambar 8 Gambaran Rangkaian Pengujian (Amelia et al., n.d.)

Fitur

$$
\begin{aligned}
& \text { - memori internal } \\
& \text { - } \mathrm{I}^{2} \mathrm{C} \text { interface } \\
& \text { - range } \pm 2000 \mathrm{gal}
\end{aligned}
$$

- konsumsi arus (standby): $90 \mu \mathrm{A}$

- konsumsi arus (processing): $300 \mu \mathrm{A}$

(Amelia et al., n.d.) melakukan 30 percobaan deteksi getaran pada saat truk melintas, dan 30 percobaan deteksi getaran saat batu seberat $11 \mathrm{~kg}$ dijatuhkan untuk pengujian alat. Pada percobaan ini, sensor gempa Omron D7S dapat mendeteksi gempa bumi berkekuatan 2.0 - 5.1 SR.

(Afrizal, Saputra, Setianingsih, \& Elektro, n.d.) memanfaatkan teknologi Internet oc Things (IoT) untuk mitigasi bencana gempa bumi. Pada jurnal penelitian ini, tidak dicantumkan metode pengujian sensor Omron D7S. Sensor ini dapat mendeteksi Peak Ground Acceleration (PGA) ketika terjadi gempa bumi. 
9. Seismometer broadband Trillium $120 \mathrm{P}$

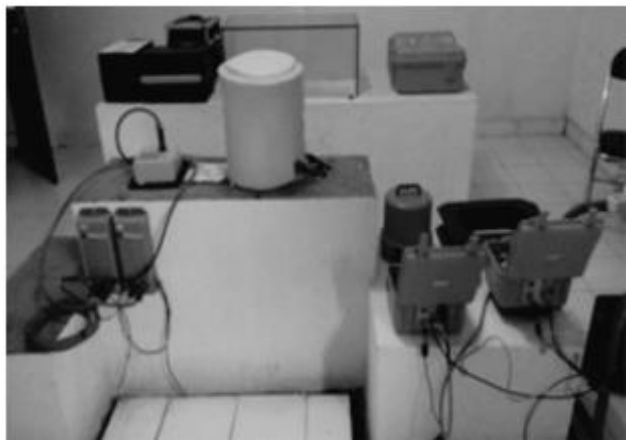

Gambar 9 Pengujian seismometer broadband Trillium 120 P (Negara \& Pratama, 2016)

Fitur
- 3 component
- broadband dengan noise rendah
- dapat digunakan untuk event lokal maupun
regional

- compact dan portable
- konsumsi tegangan rendah

(Negara \& Pratama, 2016) melakukan kalibrasi Seismometer broadband Trillium 120 P dengan cara membandingkannya dengan Seismometer short-period portable DS 04A Kedua seismometer diletakkan secara berdampingan sejak April hingga Juli 2016. Metode untuk membandingkan sinyal kedua seismometer adalah metode korelasi silang. Diperoleh nilai korelasi tinggi yang menunjukkan bahwa seismometer broadband masih dapat berfungsi dengan baik meskipun telah berusia 11 tahun.

Perbadasarkan penjabaran hasil studi literatur di atas, dapat di ambil beberapa poin penting, yaitu:

1. Untuk low budget proyek: sensor percepatan ADXL330, ADXL335, ADXL345, MPU6050, dan H48C, serta sensor getar SW-420.

2. Untuk proyek dengan dana yang lebih: sensor geophone, sensor Omron D7S, seismometer Trillium 120P.

3. ADXL330, ADXL335 dan H48C memiiki fitur yang kurang lebih sama, dan berdasarkan (Ardhi et al., 2018) ADXL335 telah dibandingkan dengan accelerometer smartphone dan error rate-nya kecil.

4. ADXL345 memiliki konsumsi daya yang kecil, range pengukuran yang lebih besar daripada akselerometer lainnya, dan memiliki antarmuka digital SPI dan $\mathrm{I}^{2} \mathrm{C}$. Dan akurasi presisi sensor ini telah di uji pada (Darmawan et al., 2019) dan (Sampurno et al., 2018) dan hasilnya bagus.

5. MPU6050 memiliki keunggulan yaitu adanya gyroscope pada sensor ini.

6. Sensor getar SW-420 dapat digunakan jika hanya membutuhkan sensor untuk deteksi ada tidaknya getaran.

7. Sensor geophone dapat digunakan untuk deteksi getaran vertikal dan horizontal, dan memiliki sensitivitas tinggi.

8. Sensor Omron D7S keluarannya berupa PGA dan memiliki range yang jauh lebih besar dibandingkan accelerometer biasa, 3-axis sensor percepatan, dan memiliki presisi yang tinggi karena sensor ini rejects impulse vibration noise.

9. Seismometer Trillium 120P memiliki noise rendah dan jangkauan pengukurannya hingga gempa regional, seismometer ini juga tahan lama hingga lebih dari 10 tahun, dan seismometer ini portable.

\section{KESIMPULAN}

Berdasarkan hasil studi literatur yang telah dilakukan, dapat ditarik kesimpulan sebagai berikut:

1. Untuk proyek low budget dan membutuhkan sensor untuk deteksi getaran pada 3 sumbu, maka dapat menggunakan sensor accelerometer ADXL330, ADXL335, ADXL345, MPU6050 maupun H48C. Namun untuk rekomendasi utama dari sensor 3-axial adalah ADXL345, Sementara apabila hanya membutuhkan sensor untuk deteksi getar, maka sensor SW-420 dapat menjadi pilihan.

2. Untuk proyek yang tidak memperhatikan harga sensor, maka sensor geophone, Omron D7S, dan Trillium 120P dapat menjadi pilihan. Ketiga sensor ini sangat direkomendasikan, keputusan pemilihan sensor dikembalikan pada kebutuhan proyek. Untuk proyek sedang, maka bisa menggunakan Omron D7S atau geophone untuk sensitivitas yang lebih tinggi. Seismometer Trillium 120P direkomendasikan untuk proyek yang lebih besar dengan kebutuhan akurasi deteksi gempa yang lebih tinggi. 


\section{DAFTAR PUSTAKA}

Afrizal, F., Saputra, R. E., Setianingsih, C., \& Elektro, F. T. (n.d.). ACCELERATION DENGAN ALGORITMA FUZZY MENGGUNAKAN TEKNOLOGI INTERNET OF THINGS EARTHQUAKE DISASTER MITIGATION BASED ON PEAK GROUND ACCELERATION WITH FUZZY ALGORITHMS USING INTERNET OF THINGS TECHNOLOGY.

Alam, H., Kusuma, B. S., \& Prayogi, A. (2020). Penggunaan Sensor Vibration Sebagai Antisipasi Gempa Bumi, 5(2), $43-52$.

Amelia, R., Priramadhi, R. A., Cahyadi, W. A., Elektro, F. T., Telkom, U., \& Network, A. N. (n.d.). ALAT PENDETEKSI GEMPA BUMI MENGGUNAKAN OMRON D7S DAN MENAMPILKAN DI RUNNING TEXT BERBASIS ARTIFICIAL NEURAL NETWORK EARTHQUAKE DETECTION DEVICE UTILIZING OMRON D7S AND DISPLAYING.

Anugerah, I., Priramadhi, R. A., Cahyadi, W. A., Elektro, F. T., Telkom, U., \& Gempa, A. (n.d.). RANCANG BANGUN ALARM GEMPA MENGGUNAKAN GEOPHONE BERBASIS ARTIFICIAL NEURAL NETWORK DESIGN OF EARTHQUAKE ALARM USING GEOPHONE BASED ON, 2-11.

Ardhi, C. K., Murti, M. A., \& Nugraha, R. (2018). Perancangan Alat Pendeteksi Gempa Menggunakan Sensor Accelerometer Dan Sensor Getar. e-Proceeding of Engineering : Vol.5, No.3 Desember 2018, 5(3), 4019-4027.

Burhannudin, M. (2020). Implementasi Sistem Komunikasi FM Pada Prototype Pendeteksi Dini Gempa, 7(2), 60-64.

CNN. (n.d.). Gempa di Indonesia Meningkat dalam 5 Tahun Terakhir. Retrieved December 7, 2020, from https://www.cnnindonesia.com/teknologi/20191201065329-199-453026/gempa-di-indonesia-meningkatdalam-5-tahun-terakhir

Components101. (n.d.). Components101 - Electronic Components Pinouts, Details \& Datasheets. Retrieved March 26, 2021, from https://components101.com/about-us

Darmawan, I. G. B., Mulyasari, R., Amirudin, A., Efendi, D. S., \& Suharno. (2019). Uji validasi instrumen akselerometer ADXL345 untuk pengukuran kerentanan gempa dengan metode HVSR. TANTANGAN DAN PELUANG RISET PERGURUAN TINGGI UNTUK MEMENUHI KEBUTUHAN DUNIA INDUSTRI BERKELANJUTAN (pp. 85-92).

Fadlilah, N. I., \& Arifudin, A. (2018). PEMBUATAN ALAT PENDETEKSI GEMPA MENGGUNAKAN ACCELEROMETER BERBASIS ARDUINO . Jurnal Evolusi, 6 .

Hidayat, Ishaq, U. M., \& Lasa, A. (2012). PERANCANGAN PENGUKUR MAGNITUDO DAN ARAH GEMPA MENGGUNAKAN SENSOR ACCELEROMETER ADXL330 MELALUI TELEMETRI, $1(2)$.

Liputan6. (n.d.). 9 Negara Paling Rawan Gempa Sedunia, Indonesia Nomor 2. Retrieved December 7, 2020, from https://www.liputan6.com/global/read/4413902/9-negara-paling-rawan-gempa-sedunia-indonesia-nomor-2

Negara, P. K. G. A., \& Pratama, I. P. D. (2016). PERBANDINGAN DATA SEISMOMETER TRILLIUM 120P RELATIF TERHADAP SEISMOMETER DS 04A DI STASIUN GEOFISIKA SANGLAH DENPASAR. Jurnal Meteorologi Dan Geofisika, 17(2), 117-122.

Priyana, Y., Laumal, F., \& Husni, E. (n.d.). Development of Earthquake Early Warning System Using ADXL335 Accelerometer, 1-5.

Sampurno, Y. P., Sugiana, A., Rusdinar, A., Elektro, F. T., \& Telkom, U. (2018). Sistem peringatan gempa bumi pada jalur kereta api earthquake warning system for railway, 5(3), 2-7.

Santoso, H., Quszaini, W., Aris, D., \& Andriawan, H. (n.d.). ALAT PENDETEKSI GEMPA BUMI MENGGUNAKAN SENSOR ACCELEROMETER MPU 6050 DAN SOLLAR CELL SEBAGAI SUMBER ENERGI LISTRIK.

Saputra, J. F., Rosmiati, M., \& Sari, M. I. (2018). Pembangunan Prototype Sistem Monitoring Getaran Gempa Menggunakan Sensor Module SW-420, 4(2442-5826), 2055.

Sharma, V. G. A. (2017). Prediction of Earthquake Using 3 Axis Accelerometer Sensor (ADXL335) and ARDUINO UNO. International Journal of Science and Research (IJSR), 6(9), 1044-1047. Retrieved from https://www.ijsr.net/archive/v6i9/ART20176803.pdf 